\title{
Effects of different feeding habits of three bivalve species on sediment characteristics and benthic diatom abundance
}

\author{
Gen Kanaya ${ }^{1, *}$, Ei Nobata ${ }^{2}$, Terumasa Toya ${ }^{2}$, Eisuke Kikuchi ${ }^{1}$ \\ ${ }^{1}$ Center for Northeast Asian Studies, Tohoku University, Kawauchi, Aoba-ku, Sendai 980-8576, Japan \\ ${ }^{2}$ Biological Institute, Graduate School of Science, Tohoku University, Aramaki-aza-Aoba, Aoba-ku, Sendai 980-8578, Japan
}

\begin{abstract}
To reveal the feeding habits of 3 bivalve species and the effects on the sediment and benthic diatoms, a field experiment was conducted in the estuarine Gamo lagoon, Japan, using enclosures stocked with bivalves. The surface-deposit feeder Macoma contabulata reduced silt-clay, total nitrogen, and total organic carbon content and the $\delta^{13} \mathrm{C}$ value of the sediment, while the surfacedeposit feeder Nuttallia olivacea and the suspension feeder Ruditapes philippinarum did not. The surface-deposit feeders reduced phytobenthic biomass (chlorophyll $a$, chl a) and diatom density at the sediment surface and increased the $\mathrm{C} / \mathrm{N}$ ratios of the sediment. In contrast, $R$. philippinarum increased chl a although it decreased benthic diatoms, suggesting the promotion of microalgal growth other than diatoms. All the bivalve species reduced the densities of the dominant diatom species differently, and M. contabulata decreased the species richness. Multidimensional scaling and 1 -way analysis of similarity revealed that the bivalves specifically modified the abundances and composition of the diatoms in relation to their feeding habits, while the relative diatom species abundances hardly changed. These data suggest that the bivalves show little selectivity when they ingest benthic diatoms. A 2-source mixing model using $\delta^{13} \mathrm{C}$ values revealed that benthic diatoms were the more important carbon source (>69\%) for the deposit-feeding bivalves, both in natural habitats and in enclosures. In contrast, $R$. philippinarum obtained $61 \%$ carbon from suspended solids (SS) in the natural habitat, whereas in the enclosures it obtained $62 \%$ carbon from benthic diatoms. The dietary change of this species might be related to the supply of SS and resuspended sediment.
\end{abstract}

KEY WORDS: Infaunal bivalves - Feeding habit - Bioturbation - Benthic diatom · Sediment • Stable isotope Resale or republication not permitted without written consent of the publisher

\section{INTRODUCTION}

In estuaries, suspended organic particles, including phytoplankton, are precipitated onto the sediment surface (Heip et al. 1995). A considerable biomass of autochthonous microphytobenthos, one of the most important primary producers in shallow unvegetated estuarine flats, is also found at the sediment surface (MacIntyre et al. 1996, Cahoon 1999). The microphytobenthic community is often dominated by benthic diatoms, which are a particularly important food source for benthic consumers (Plante-Cuny \& Plante 1986, MacIntyre et al. 1996, Miller et al. 1996, Cahoon
1999). These autochthonous and allochthonous organic particles are used as food sources by suspension- and deposit-feeding animals (Heip et al. 1995).

Characteristics of sediment, such as grain size distribution, organic content, and microphytobenthic biomass, including benthic diatoms, are frequently modified by benthic consumers through their feeding behavior and feces/pseudofeces excretion (reviewed by Rhoads 1974, Lopez \& Levinton 1987, Graf \& Rosenberg 1997). Among benthic consumers, bivalves are an important link in the estuarine food chain from primary producers to epibenthic consumers (Heip et al. 1995) and are one of the most important bioturbators in soft 
bottom environments (Rhoads 1974, Graf \& Rosenberg 1997). In fact, many ecologists have shown that bivalve species modify sediment properties and microphytobenthic biomass differently in relation to their feeding ecologies (Tsuchiya \& Kurihara 1980, Swanberg 1991, Page et al. 1992, Bartoli et al. 2001). In general, surface-deposit feeders ingest potential food items at the sediment surface and, as a result, reduce the organic content and/or microalgal biomass (Tsuchiya \& Kurihara 1980, Page et al. 1992, Smith et al. 1996, Hillebrand et al. 2000). In contrast, suspension feeders collect organic particles in the water column and deposit feces and pseudofeces, which are rich in organic matter, onto the sediment surface (i.e. biodeposition; reviewed by Graf \& Rosenberg 1997). Therefore, in order to elucidate the bioturbation effects of a benthic animal, it is necessary to understand which materials the animal actually assimilates and from which the animal collects food items.

It has been reported that some infaunal animals could modify the community structure of benthic microalgae as a result of highly selective feeding (Smith et al. 1996, Hillebrand et al. 2000, Hagerthey et al. 2002). Particle collection, filtration, and rejection by bivalves are often highly selective processes (Self \& Jumars 1988, Defossez \& Hawkins 1997, Navarro \& Thompson 1997, Sobral \& Widdows 2000); therefore, if a bivalve is a highly selective feeder, it might affect microphytobenthic species in different ways, and the community structure would change in a fixed manner in response to the bivalve species. However, little is known about the relationships between bivalves and the community structure of benthic microalgae (e.g. Page et al. 1992).

Three bivalve species, Ruditapes philippinarum, Nuttallia olivacea, and Macoma contabulata, are the dominant bivalves in a shallow estuarine lagoon, Gamo (Japan) (Kurihara et al. 2000). R. philippinarum is a typical infaunal suspension feeder (Defossez \& Hawkins 1997) that has a short inhalant siphon located at or below the sediment surface (G. Kanaya pers. obs.). This species is expected to have a biodeposition effect on the sediment surface, for instance, the enrichment of fine organic particles and microalgal biomass, as is reported for the other suspension-feeding bivalves (Swanberg 1991, Graf \& Rosenberg 1997, Navarro \& Thompson 1997, Bartoli et al. 2001). In contrast, $M$. contabulata and $N$. olivacea seem to be surface-deposit feeders, but little is known about their feeding habits. In the Gamo lagoon, one can observe that $M$. contabulata extends a long inhalant siphon about 3 to $5 \mathrm{~cm}$ from the burrow and collects food items in the vicinity of the burrow during low tide. Thus, this species would be a surface-deposit feeder and is expected to remove organic materials and microphyto- benthos from the sediment surface, as is reported for the other deposit-feeding bivalves (e.g. Page et al. 1992). N. olivacea had also been reported as a surfacedeposit feeder (Tsuchiya \& Kurihara 1980), while Akiyama (1988) has suggested that the species is better adapted to filter feeding than $M$. contabulata, based on their morphological differences. Thus, $N$. olivacea would be a more facultative deposit feeder than $M$. contabulata and is expected to modify the sediment properties differently.

In this study, a field experiment was conducted in the lagoon using enclosures stocked with these bivalves. At the end of the experiment, sediment properties were analyzed and benthic diatoms at the sediment surface were collected. In order to examine the feeding ecology of the bivalves, carbon and nitrogen stable isotope analyses, which are widely used to trace food sources of animals (e.g. Couch 1989, Page 1997, Kurata et al. 2001), were also conducted. Specifically, the aims of this study were to (1) test the effects of the bivalves on sediment characteristics, (2) define the feeding habits of Macoma contabulata and Nuttallia olivacea, (3) reveal the main food sources of the bivalves, and (4) estimate the effects of the bivalves on the benthic diatom community structure, in relation to feeding ecology.

\section{MATERIALS AND METHODS}

Study sites and organisms. The shallow estuarine brackish Gamo lagoon $\left(0.11 \mathrm{~km}^{2}\right)$ is situated on the north side of the Nanakita River estuary in NE Japan (Fig. 1). A stone levee with 3 water gates restricts water exchange. The salinity fluctuates tidally from near 0 to over 30 psu (Kurihara et al. 2000). Stn E, located in a semi-closed shallow inlet, was selected for the field experiment (Fig. 1). The area is relatively undisturbed since there were no or only minimal tidal currents. The minimum water depth at Stn E was $10 \mathrm{~cm}$ at mean low low water.

Ruditapes philippinarum, Nuttallia olivacea, and Macoma contabulata are the dominant bivalves in the Gamo lagoon and sometimes found together (Kurihara et al. 2000). Their mean densities in the lagoon were 105 ( $R$. philippinarum), 531 ( $N$. olivacea), and 183 (M. contabulata) ind. $\mathrm{m}^{-2}$ (G. Kanaya unpubl. data). $M$. contabulata prefers a muddier habitat than the other 2 species (ranges of silt-clay content in their natural habitat: $R$. philippinarum; 2 to $28 \%$; N. olivacea; 1 to $23 \%$; and $M$. contabulata; 2 to $67 \%$; G. Kanaya unpubl. data).

Experimental set-up. The field experiment was conducted from 15 August to 14 November 2001 at Stn E. Adult Ruditapes philippinarum, Nuttallia olivacea, and 


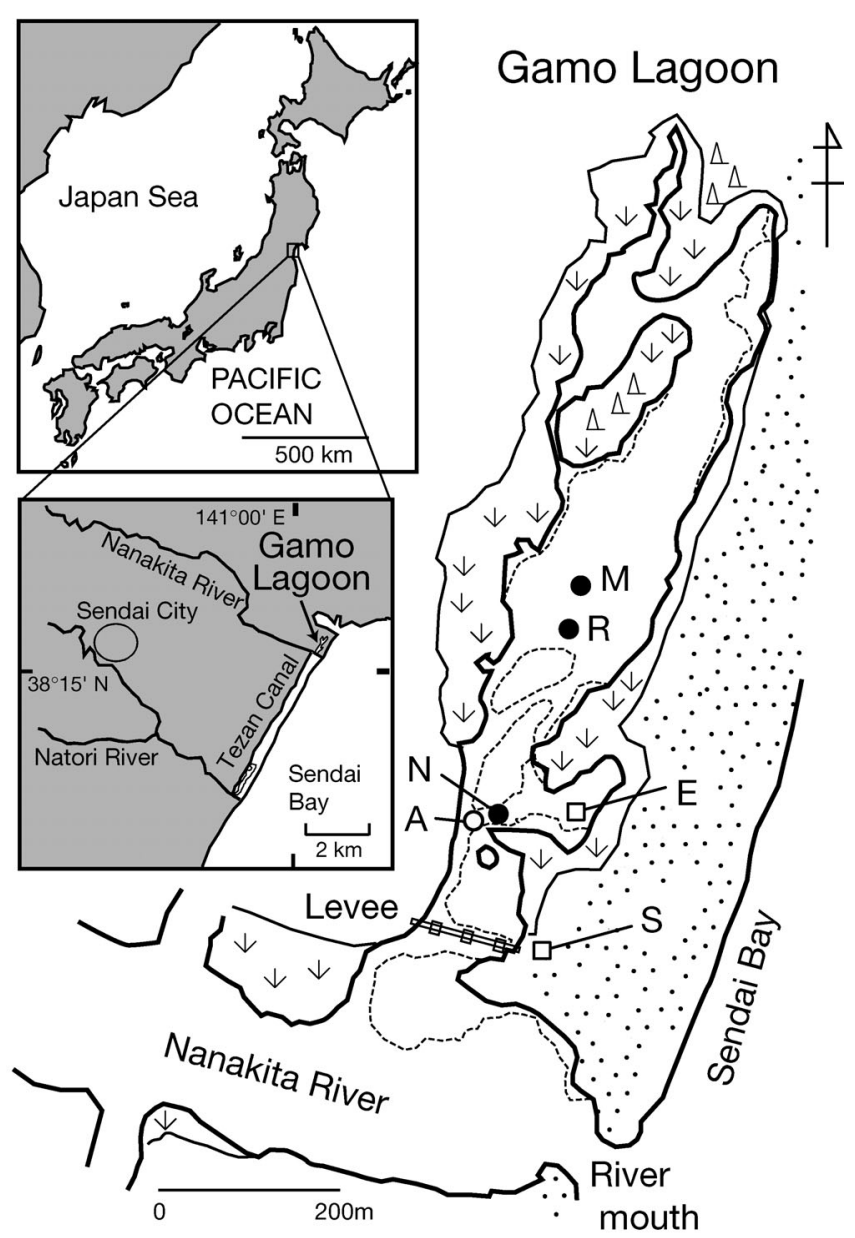

$\Delta_{\Delta}^{\Delta} \Delta ;$ pine trees ${ }^{\downarrow}{ }^{\downarrow} \downarrow$; reed marsh $\therefore \because ;$; sand dune --.-- ; low water line at spring tide

Fig. 1. Map of the study site. $\square$ : stations where the experiment was conducted (Stn E and the enclosure, Stn S); •: stations where bivalves were collected (Stn R for Ruditapes philippinarum, Stn N for Nuttallia olivacea and Stn M for Macoma contabulata); O: station where benthic diatoms and suspended solids for stable isotope analyses were sampled (Stn A)

Macoma contabulata were collected at Stns $\mathrm{R}, \mathrm{N}$, and $\mathrm{M}$ (Fig. 1), respectively, where they occurred at the highest respective densities. Silt-clay contents at the Stns $\mathrm{R}, \mathrm{N}$, and $\mathrm{M}$ were $3.3,2.0$, and $5.4 \%$, respectively $(\mathrm{n}=1)$. After $12 \mathrm{~h}$ of incubation in the laboratory with lagoon water $\left(23\right.$ to $\left.25^{\circ} \mathrm{C}\right)$, dead or low-activity individuals were removed. Subsequently, shell lengths were measured using calipers $( \pm 0.1 \mathrm{~mm}$ accuracy). $N$. olivacea $(37.4 \pm 4.2 \mathrm{~mm})$ and $M$. contabulata $(38.4 \pm$ $4.6 \mathrm{~mm}$ ) were similar in shell length, whereas $R$. philippinarum $(23.9 \pm 3.8 \mathrm{~mm})$ was smaller (Bonferroni's multiple comparison, $\mathrm{p}<0.05$ ) (Table 1). For stable isotope analyses, 3 individuals of each bivalve species were also collected at the stations and kept frozen $\left(-20^{\circ} \mathrm{C}\right)$.
Table 1. Number of survivors and shell length for 3 bivalve species; 10 individuals were introduced initially. Different letters indicate significant differences in shell heights among species (Bonferroni's multiple comparison, $\mathrm{p}<0.05$ ). p-values show significant differences between the shell lengths at the beginning and at the end of the experimental period ( $t$-test)

\begin{tabular}{|c|c|c|c|c|}
\hline \multirow[t]{2}{*}{$\begin{array}{l}\text { Replicate } \\
\text { name }\end{array}$} & \multirow[t]{2}{*}{$\begin{array}{l}\text { Survivors } \\
\text { (ind.) }\end{array}$} & \multicolumn{2}{|c|}{$\begin{array}{c}\text { Shell length } \\
(\text { mean } \pm 1 \mathrm{SD}, \mathrm{mm})\end{array}$} & \multirow[t]{2}{*}{$t$-test } \\
\hline & & Initial & Final & \\
\hline \multicolumn{5}{|c|}{ Ruditapes philippinarum (+Rud) } \\
\hline $\mathrm{R} 1$ & 102 & $23.9 \pm 3.8 \mathrm{a}$ & $36.4 \pm 3.1 \mathrm{a}$ & $\mathrm{p}<0.001$ \\
\hline R2 & 10 & $(\mathrm{n}=50)$ & $(\mathrm{n}=45)$ & $t=-17.43$ \\
\hline R3 & 10 & & & $\mathrm{df}=93$ \\
\hline R4 & 10 & & & \\
\hline R5 & 10 & & & \\
\hline \multicolumn{5}{|c|}{ Nuttallia olivacea (+Nut) } \\
\hline N1 & 93 & $37.4 \pm 4.2 \mathrm{~b}$ & $46.5 \pm 3.6 \mathrm{~b}$ & $\mathrm{p}<0.001$ \\
\hline N2 & 10 & $(\mathrm{n}=50)$ & $(\mathrm{n}=44)$ & $t=-11.21$ \\
\hline N3 & 10 & & & $\mathrm{df}=92$ \\
\hline N4 & 10 & & & \\
\hline N5 & 10 & & & \\
\hline \multicolumn{5}{|c|}{ Macoma contabulata (+Mac) } \\
\hline M1 & 93 & $38.4 \pm 4.6 \mathrm{~b}$ & $45.8 \pm 4.4 \mathrm{~b}$ & $\mathrm{p}<0.001$ \\
\hline M2 & 9 & $(\mathrm{n}=50)$ & $(\mathrm{n}=35)$ & $t=-7.45$ \\
\hline M3 & 5 & & & $\mathrm{df}=83$ \\
\hline M4 & 8 & & & \\
\hline M5 & 9 & & & \\
\hline
\end{tabular}

Plastic pots (23.5 $\mathrm{cm}$ i.d. $\times 19.5 \mathrm{~cm}$ depth) were used as enclosures that were filled up to $1 \mathrm{~cm}$ from the top with sieved azoic sand ( $<1 \mathrm{~mm}$ mesh; silt-clay, $0.6 \pm$ $1.0 \%$; TOC, $0.09 \pm 0.02 \%$; $=5$ ) collected at Stn $\mathrm{S}$ located in the sand dune (Fig. 1). Initial $\delta^{13} \mathrm{C}$ value of the sediment was $-23.7 \pm 0.3 \%$ o $(n=3)$. A total of 20 enclosures ( 4 treatments by 5 replicates) were buried into the sediment at $1 \mathrm{~m}$ intervals in a square area $(4 \times$ $5 \mathrm{~m}$ ). Openings of the enclosures were kept $5 \mathrm{~cm}$ above the ambient sediment to maintain submergence. Four treatments were assigned to the 4 rows in the plots: (1) control (0 bivalves enclosure ${ }^{-1}$ ), (2) + Ruditapes philippinarum (10 ind. enclosure ${ }^{-1},+$ Rud), (3) +Nuttallia olivacea (10 ind. enclosure ${ }^{-1},+$ Nut), and (4) +Macoma contabulata (10 ind. enclosure ${ }^{-1}$, +Mac). The enclosures were coded C1 to C5 (control), R1 to R5 (+Rud), N1 to N5 (+Nut), and M1 to M5 (+Mac). The bivalve density in the enclosures (250 ind. $\mathrm{m}^{-2}$ ) was 2.5 and 1.4 times higher than the mean densities in the lagoon for $R$. philippinarum and $M$. contabulata, while less than half for $N$. olivacea (G. Kanaya unpubl. data). Environmental homogeneity in the area was checked after the experiment. Tidal current was uniformly low in the area $\left(<2 \mathrm{~cm} \mathrm{~s}^{-1}\right)$, and the raised enclosure lip did not affect the current. Silt-clay content of the ambient sediment beside the enclosures was $4.3 \pm 1.4 \%(\mathrm{n}=20)$ and did not differ significantly among either the treatments or the repli- 
cates (2-way ANOVA, df $=3,4,12, F=1.67,1.81, \mathrm{p}>$ $0.05)$.

At the end of the experiment, the bivalves were collected using a $1 \mathrm{~mm}$ mesh sieve. One individual from each enclosure was frozen $\left(-20^{\circ} \mathrm{C}\right)$ for stable isotope analyses, while the others were preserved in $4 \%$ neutralized formalin for shell length measurements using calipers $( \pm 0.1 \mathrm{~mm}$ accuracy). Shell length increased by 7 to $12 \mathrm{~mm}$ over the period for each species ( $t$-test, $\mathrm{p}<$ 0.001, Table 1). Macoma contabulata showed relatively high mortality compared to the other 2 species (Table 1), and 1 enclosure in the +Mac treatment (M3) was excluded from further analyses since $50 \%$ of the added bivalves were dead.

Analytical methods. A 0 to $1 \mathrm{~cm}$ section of the sediment was taken using a core $(2.8 \mathrm{~cm}$ i.d.) from each enclosure at the end of the experiment (14 November 2001). The sediment was dried $\left(70^{\circ} \mathrm{C}, 48 \mathrm{~h}\right)$ and weighed for total organic carbon (TOC), total nitrogen (TN), and silt-clay content analyses. TOC and TN contents were determined using an elemental analyzer (NC-2500; CE Instruments) after an acid treatment with $1 \mathrm{M} \mathrm{HCl}$ to remove carbonates. Silt-clay content was measured by wet sieving (0.063 mm mesh). An additional sediment core $(2.8 \mathrm{~cm}$ i.d.) was taken from each enclosure. $\mathrm{Chl} \mathrm{a}$ in the 0 to $1 \mathrm{~cm}$ section was extracted with $90 \%$ acetone, transferred into pure hexane, and the concentration was determined using a spectrophotometer (Model 101; HITACHI) at wavelengths of 663 and $750 \mathrm{~nm}$ (Whitney \& Darley 1979). Chl a data were evaluated in triplicate for each treatment, since some of the samples could not be analyzed successfully.

Stable isotopic analyses. The bivalves collected from the natural habitats (15 August 2001) and from the enclosures (14 November 2001) were regarded as the 'initial' and 'final' samples, respectively. After being thawed at room temperature for $4 \mathrm{~h}$, bivalve muscle was picked out, rinsed in Millipore water, and freezedried (24 h). The sample was ground into a powder and treated with a chloroform-methanol mixture solution ( $2: 1$ by volume) for $24 \mathrm{~h}$ to remove lipids. The solution was removed by filtering through a precombusted $\mathrm{GF} / \mathrm{F}$ filter $\left(500^{\circ} \mathrm{C}, 2 \mathrm{~h}\right)$. At the end of the experiment, a 0 to $1 \mathrm{~cm}$ section of the sediment was taken using a core $(2.8 \mathrm{~cm}$ i.d.) from each enclosure. The sediment was dried $\left(70^{\circ} \mathrm{C}, 48 \mathrm{~h}\right)$ and treated with $1 \mathrm{M} \mathrm{HCl}$ to remove carbonates. To collect suspended solids (SS), lagoon water was sampled at Stn E during ebb tide on 19 November 2001. Bulk SS in the water was collected by filtering through a precombusted GF/F filter $\left(500^{\circ} \mathrm{C}, 2 \mathrm{~h}\right)$. Lagoon water was also sampled at Stn A (Fig. 1) during ebb tide on 20 August, 15 October, and 13 November 2001. These samples were regarded as representatives of the lagoon water, which was discharged into the river during ebb tide. The water was filtered in sequence through 250, 75, and $25 \mu \mathrm{m}$ meshes. The fraction passing through the $25 \mu \mathrm{m}$ mesh and the particles remaining on the meshes were filtered through a precombusted $\mathrm{GF} / \mathrm{F}$ filter $\left(500^{\circ} \mathrm{C}, 2 \mathrm{~h}\right)$ and coded as SS1 $(<25 \mu \mathrm{m}), \mathrm{SS} 2(25$ to $<75 \mu \mathrm{m})$, and SS3 $(75$ to $<250 \mu \mathrm{m})$. To collect benthic diatoms, sediment (0 to $1 \mathrm{~cm}$ depth) was sampled at the tidal flat close to Stn A on 23 June, 20 July, 25 August, and 22 December 2001, in triplicate, and coded as BD1, $\mathrm{BD} 2, \mathrm{BD} 3$, and BD4, respectively. Benthic diatoms in the sediment were extracted with the aid of their phototactic movement (Couch 1989). At Stn A, the microphytobenthic community was primarily dominated by diatoms during the period ( $>99 \%$ ), and $76 \pm 18 \%$ of the diatoms were pennate and non-araphic (E. Nobata unpubl. data). Since the method mainly extracts motile microalgae, including pennate, non-araphic diatoms (T. Toya unpubl. data), the samples would be representative of the microphytobenthic community at the station. During the isotopic analyses, 3 replicated samples for BD2, BD3, and BD4 were analyzed together; the $\delta^{15} \mathrm{~N}$ value of BD4 was not measurable, since the quantity of samples was lower.

All samples were freeze-dried (24 h) and kept in a freezer $\left(-20^{\circ} \mathrm{C}\right)$ until the analyses. Carbon and nitrogen stable isotope ratios were determined using a mass spectrometer (DELTA plus; Finnigan Mat). Isotope ratios are represented in the delta notation, such that:

$\delta^{13} \mathrm{C}$ or $\delta^{15} \mathrm{~N}=(R$ sample $/ R$ standard -1$) \times 1000(\%)$ where $R$ is the ${ }^{13} \mathrm{C} /{ }^{12} \mathrm{C}$ or ${ }^{15} \mathrm{~N} /{ }^{14} \mathrm{~N}$ ratio for $\delta^{13} \mathrm{C}$ or $\delta^{15} \mathrm{~N}$, respectively. Peedee belemnite and atmospheric nitrogen were used as references for $\delta^{13} \mathrm{C}$ and for $\delta^{15} \mathrm{~N}$, respectively. Analysis errors were within $\pm 0.2 \%$ for both $\delta^{13} \mathrm{C}$ and $\delta^{15} \mathrm{~N}$.

For each bivalve species, the percentage contributions of SS and benthic diatoms as their carbon sources were estimated using a simple linear, 2-source mixing model (Phillips \& Koch 2002)

$$
\begin{aligned}
& \delta^{13} \mathrm{C}_{M}= \\
& \quad f_{X}\left(\delta^{13} \mathrm{C}_{X}+\Delta \Delta^{13} \mathrm{C}_{\text {tissue }-X}\right)+f_{Y}\left(\delta^{13} \mathrm{C}_{Y}+\Delta^{13} \mathrm{C}_{\text {tissue }-Y}\right) \\
& 1=f_{X}+f_{Y}
\end{aligned}
$$

where the subscripts $X, Y$, and $M$ represent 2 food sources and the mixture (bivalve), respectively; $f$ represents the fractional contribution of carbon from each food source to the bivalve's diet, and $\Delta^{13} C_{\text {tissue }-X}$ is the trophic enrichment. We assumed the SS and benthic diatoms as 2 main food sources and the trophic enrichment as $0.5 \%$ (France \& Peters 1997). The mean $\delta^{13} \mathrm{C}$ values of $\mathrm{SS}$, benthic diatoms, and the bivalves (both initial and final) were used.

Benthic diatoms. Surface sediment (0 to $1 \mathrm{~cm}$ depth) in each enclosure was collected using a corer $(2.8 \mathrm{~cm}$ i.d.) at the end of the experiment and was preserved in 
$2 \%$ glutaraldehyde. After the sample was diluted, diatoms were identified to genus and to species, if possible (based on Mizuno 1964, Yamaji 1966, Takano 1990, Kojima et al. 1995, Chihara \& Murano 1997), and were counted using a phase contrast microscope $(\times 400)$.

Statistics. Data are given as means with standard deviations. A 1-way analysis of variance (ANOVA) was used to investigate differences among the treatments, and the Bonferroni a posteriori test was used for pairwise comparisons. Homogeneity of the data was tested by the Bartlett test and, when necessary, $\log _{10}(x+1)$ or square root transformation was performed. Changes in stable isotopic values of the bivalves and the enclosure sediment during the period were tested by a $t$-test. Community structures of benthic diatoms were examined with nonmetric multidimensional scaling (MDS) using the software PCORD (McCune \& Mefford 1999). Differences in the community structure among treatments were tested by a 1-way analysis of similarities (ANOSIM) using the software PRIMER (Clarke \& Gorley 2001). MDS and 1-way ANOSIM analyses were conducted based on the Bray-Curtis similarity index, calculated from both the absolute and relative abundance data sets.

\section{RESULTS}

\section{Sediment characteristics}

The sediment environmental factors significantly differed among the treatments (1-way ANOVA, Table 2). Silt-clay, TN, and TOC contents (Fig. 2) were 40 to $45 \%$ lower in the +Mac treatment than in the control (Bonferroni's multiple comparison, p < 0.05), while
Table 2. A 1-way ANOVA for the means of sediment properties at the enclosure, among the different treatments. TN: total nitrogen; TOC: total organic carbon; Chl a: chlorophyll a

\begin{tabular}{|lccc|}
\hline Variable & df & $F$ & $p$ \\
\hline Silt-clay & 3,15 & 7.89 & $<0.01$ \\
TN & 3,15 & 9.59 & $<0.001$ \\
TOC & 3,15 & 6.50 & $<0.01$ \\
Chl $a$ & 3,8 & 7.20 & $<0.05$ \\
Benthic diatom & 3,15 & 33.44 & $<0.001$ \\
C/N & 3,15 & 7.64 & $<0.01$ \\
$\delta^{13} \mathrm{C}$ value & 3,15 & 7.80 & $<0.01$ \\
$\delta^{15} \mathrm{~N}$ value & 3,15 & 0.97 & $>0.05$ \\
\hline
\end{tabular}

there were no significant differences among the +Rud, + Nut, and control treatments $(p>0.05)$. The silt-clay content in the +Mac treatment $(2.9 \pm 0.1 \%)$ was significantly lower than those in the control $(4.6 \pm 0.8 \%)$, $+\operatorname{Rud}(3.9 \pm 0.8 \%)$, and + Nut $(4.6 \pm 0.7 \%)$ treatments (Fig. 2a). The silt-clay contents in the control, +Rud, and + Nut treatments were similar to those of the ambient unenclosed sediment $(4.3 \pm 1.4 \%)$. Mean diatom density in the +Mac treatment was approximately onethird and in the +Rud and +Nut treatments was approximately two-thirds the density in the control (Bonferroni's multiple comparison, $\mathrm{p}<0.05$, Fig. 3b). We found no significant difference in benthic diatom density between the +Rud and +Nut treatments (Bonferroni's multiple comparison, $\mathrm{p}>0.05$ ); however, chl a was 1.5 to 2 times higher in the +Rud treatment than in the +Nut and +Mac treatments $(p<0.05$, Fig. 3a). Sediment $\mathrm{C} / \mathrm{N}$ ratios were also significantly higher in the presence of Nuttallia olivacea $(9.4 \pm 0.5)$ and Macoma contabulata $(9.2 \pm 0.5)$ than in the control $(8.3 \pm 0.3)$ (Bonferroni's multiple comparison, $\mathrm{p}<0.05$, Fig. 3c). (a) Silt-Clay

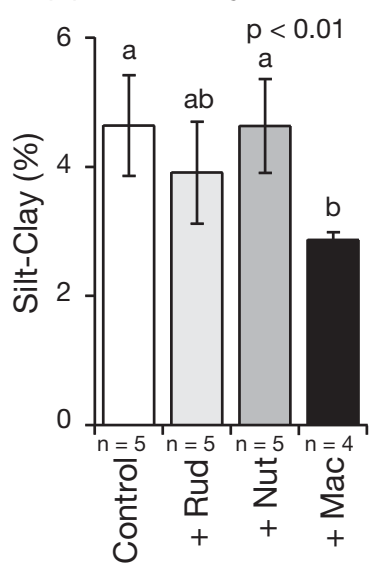

(b) TN

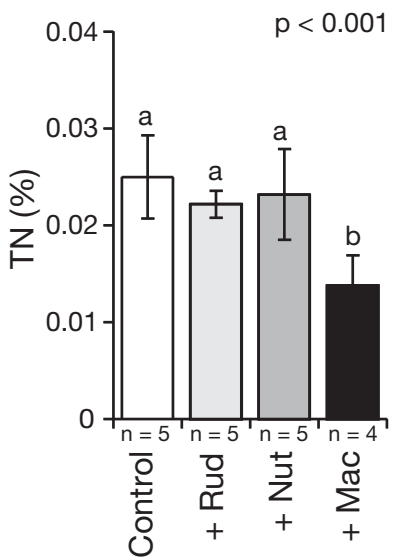

(c) TOC

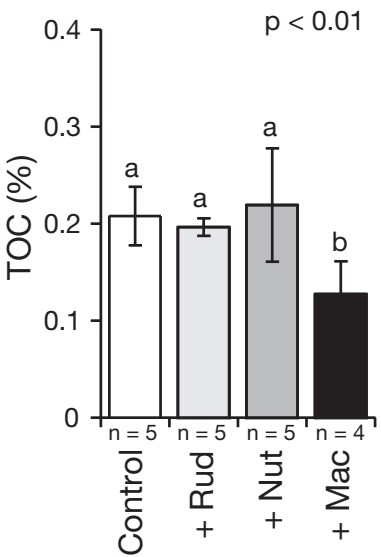

Type of treatment

Fig. 2. (a) Silt-clay, (b) total nitrogen (TN), and (c) total organic carbon (TOC) content of the sediment surface in the enclosures. Bars represent mean $\pm 1 \mathrm{SD}$; $\mathrm{p}$-values for 1-way ANOVA are shown; different letters indicate significant differences between means (Bonferroni's multiple comparison, $\mathrm{p}<0.05$ ) (for treatment abbreviations, see Table 1) 
(a) $\mathrm{Chl} \mathrm{a}$

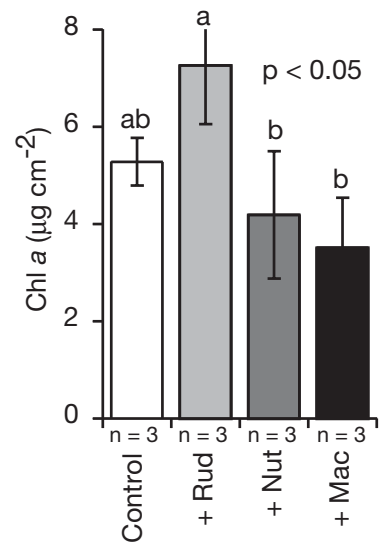

(b) Benthic diatom

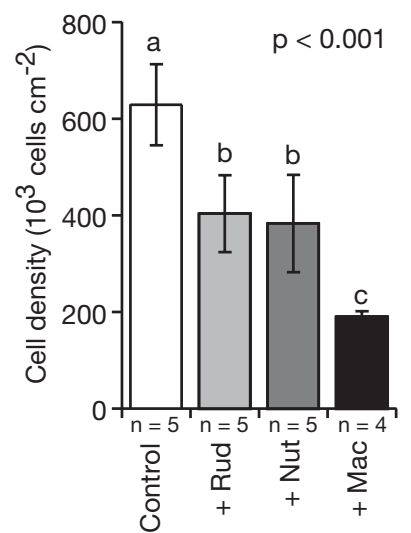

(c) $\mathrm{C} / \mathrm{N}$

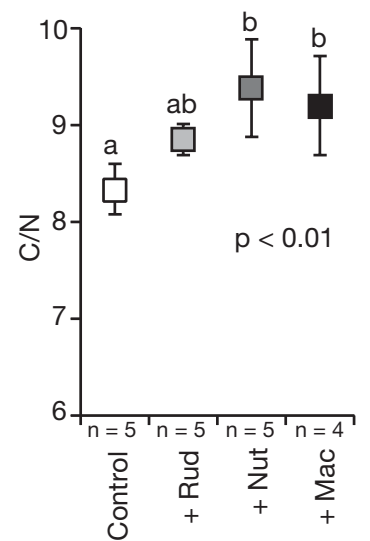

Type of treatment

Fig. 3. (a) Chlorophyll a content, (b) benthic diatom densities, and (c) $\mathrm{C} / \mathrm{N}$ ratio of the sediment surface in the enclosures. Bars represent mean $\pm 1 \mathrm{SD}_{\text {; }} \mathrm{p}$-values for 1 -way ANOVA are shown; different letters indicate significant differences between means (Bonferroni's multiple comparison, $\mathrm{p}<0.05$ )

\section{Diatoms}

We found $\geq 26$ diatom species of 10 to $80 \mu \mathrm{m}$ cell sizes in the enclosures (Table 3); other microalgae such as cyanobacteria and green algae were rarely found $(<1 \%$ of the total microalgae). The benthic diatom community was dominated by pennate diatoms such as Navicula trivialis, Synedra acus, and Amphora sp. 1 (38, 16, and $9.9 \%$ of the total diatoms, respectively); the species composition was similar to those in the natural sediment at Stn A during the period, but was very different from that of the lagoon water (E. Nobata unpubl. data). Thus, a large proportion of the diatoms found in the enclosures seemed to be primarily benthic.

The bivalves significantly changed the density of several of the 8 dominant diatom species (1-way ANOVA, Table 4), albeit with different intensities (Fig. 4). All the bivalve species significantly reduced the densities of Synedra acus and Amphora sp. 1 (Bonferroni's multiple comparison, $\mathrm{p}<0.05$ ), while only Macoma contabulata reduced the densities of Navicula trivialis, Nitzschia sp. 1 , and Triblionella sp. $(\mathrm{p}<0.05)$. Species richness of benthic diatoms was also significantly changed by the bivalves (1-way ANOVA, see Table 4). Species richness was significantly lower in the +Mac treatment (14.4 \pm 1.8) than in the control $(18.2 \pm 1.9)$ (Bonferroni's multiple comparison, $\mathrm{p}<0.05$, Fig. 5), while it did not differ among the +Rud $(15.4 \pm 0.9)$, +Nut $(16.0 \pm 1.4)$, and control treatments $(\mathrm{p}>0.05)$. Some of the rare diatom species disappeared in the presence of $M$. contabulata, whereas the dominant species did not.

The MDS plot using absolute abundances clearly showed the species-specific modification of the benthic diatom community by the bivalves (Fig. 6a), and a
Table 3. Taxa, approximate cell size (longest length of the cell) and mean density $(n=19)$ of benthic diatoms found at the sediment surface. P: pennate diatom; C: centric diatom

\begin{tabular}{|lcccc|}
\hline Taxon & Class & $\begin{array}{c}\text { Cell } \\
\text { size } \\
(\mu \mathrm{m})\end{array}$ & $\begin{array}{c}\text { Mean } \\
\left(10^{3} \text { cells cm }^{-2}\right)\end{array}$ & $\begin{array}{c}\text { Relative } \\
\text { dence }\end{array}$ \\
& & & & \\
& & & & \\
& & & & \\
Navicula trivialis & $\mathrm{P}$ & 20 & 150 & 38 \\
Navicula sp. 1 & $\mathrm{P}$ & 20 & 18 & 4.6 \\
Navicula salinarum & $\mathrm{P}$ & 20 & 5.9 & 1.5 \\
Navicula sp. 2 & $\mathrm{P}$ & 20 & 2.7 & 0.7 \\
Amphora sp. 1 & $\mathrm{P}$ & 20 & 39 & 9.9 \\
Amphora sp. 2 & $\mathrm{P}$ & 20 & 8.0 & 2.0 \\
Nitzschia sp. 1 & $\mathrm{P}$ & 40 & 22 & 5.6 \\
Nitzschia longissima & $\mathrm{P}$ & 40 & 7.4 & 1.9 \\
Nitzschia sp. 2 & $\mathrm{P}$ & 20 & 0.3 & 0.1 \\
Triblionella sp. & $\mathrm{P}$ & 20 & 9.4 & 2.4 \\
Surrirella sp. 1 & $\mathrm{P}$ & 20 & 7.5 & 1.9 \\
Surrirella sp. 2 & $\mathrm{P}$ & 40 & 3.7 & 0.9 \\
Achnanthes sp. & $\mathrm{P}$ & 20 & 2.9 & 0.7 \\
Pinnularia sp. & $\mathrm{P}$ & 40 & 6.4 & 1.6 \\
Gyrosigma sp. & $\mathrm{P}$ & 80 & 7.3 & 1.8 \\
Pleurosigma sp. & $\mathrm{P}$ & 80 & 0.6 & 0.1 \\
Amphiprora sp. & $\mathrm{P}$ & 80 & 0.7 & 0.2 \\
Synedra acus & $\mathrm{P}$ & 60 & 62 & 16 \\
Synedra sp. & $\mathrm{P}$ & 40 & 15 & 3.8 \\
Bacillaria sp. & $\mathrm{P}$ & 40 & 8.1 & 2.0 \\
Fragilaria sp. & $\mathrm{P}$ & 20 & 0.4 & 0.1 \\
Rhizosolenia sp. & $\mathrm{C}$ & 40 & 0.2 & 0.0 \\
Cyclotella sp. & $\mathrm{C}$ & 20 & 12 & 3.1 \\
Thalassiosira sp. & $\mathrm{C}$ & 10 & 1.9 & 0.5 \\
Melosira sp. & $\mathrm{C}$ & 20 & 1.9 & 0.5 \\
Melosira varians & $\mathrm{C}$ & 20 & 1.5 & 0.4 \\
Pennate diatoms & & & 378 & 96 \\
Centric diatoms & & & 18 & 4 \\
\hline
\end{tabular}


Table 4. A 1-way ANOVA for the mean densities of the 8 dominating diatom species and the species richness at the enclosure sediment surface, among treatments

\begin{tabular}{|lcrl|}
\hline Variable & df & $F$ & $\mathrm{p}$ \\
\hline Navicula trivialis & 3,15 & 11.35 & $<0.001$ \\
Navicula sp. 1 & 3,15 & 1.52 & $>0.05$ \\
Amphora sp. 1 & 3,15 & 12.13 & $<0.001$ \\
Nitzschia sp. 1 & 3,15 & 3.73 & $<0.05$ \\
Triblionella sp. & 3,15 & 8.45 & $<0.01$ \\
Synedra acus & 3,15 & 27.98 & $<0.001$ \\
Synedra sp. & 3,15 & 0.44 & $>0.05$ \\
Cyclotella sp. & 3,15 & 2.57 & $>0.05$ \\
Species richness & 3,15 & 6.06 & $<0.01$ \\
\hline
\end{tabular}

1-way ANOSIM demonstrated that the community structure differed significantly among the treatments (Global R = 0.664, p < 0.001, Table 5). On the MDS plot, the samples in the control and +Mac treatments were distinctly separated from each other, and the samples in the +Nut and +Rud treatments were intermediate between the control and +Mac treatments. Pairwise comparison of 1-way ANOSIM found significant differences in the diatom community structure among treat- ments ( $p<0.05$, Table 5), except between the +Nut and +Rud treatments $(\mathrm{p}>0.05)$. The MDS plot using relative abundances showed that the samples in each treatment were not separated clearly from each other (Fig. 6b), and a 1-way ANOSIM could not detect significant differences among the treatments (Global $\mathrm{R}=$ 0.078, p > 0.05, Table 5).

\section{Stable isotope ratios}

As shown in Fig. 7 , the final $\delta^{13} \mathrm{C}$ values of the bivalves (Ruditapes philippinarum, $-18.9 \pm 0.3 \%$; Nuttallia olivacea, $-18.1 \pm 0.8 \%$; and Macoma contabulata, $-17.9 \pm 1.3 \%$ ) were much closer to those of benthic diatoms $(\mathrm{BD} 1,-15.6 \pm 1.0 \%$; $\mathrm{BD} 2,-15.2 \%$; BD3, $-19.4 \%$; and BD4 [not plotted], $-18.4 \%$ ) than to those of SS (SS1, $-23.4 \pm 0.5 \%$; SS2, $-24.3 \pm 0.6 \%$; SS3, $-25.0 \pm 0.9 \%$; and SS at Stn E, $-22.7 \pm 0.1 \%$ ) or the enclosure sediment (control, $-22.4 \pm 0.3 \%$; +Rud, $-22.6 \pm 0.4 \%$; +Nut, $-22.4 \pm 0.3 \%$; and $+\mathrm{Mac}_{,}-23.7 \pm$ $0.8 \%$ ). Final $\delta^{15} \mathrm{~N}$ values of the bivalves ranged from 9.7 to $11.4 \%$ ( $R$. philippinarum, $9.7 \pm 0.2 \%$; $N$. olivacea, $10.2 \pm 0.3 \%$; and M. contabulata, $11.4 \pm 0.5 \%$ o). $\delta^{15} \mathrm{~N}$

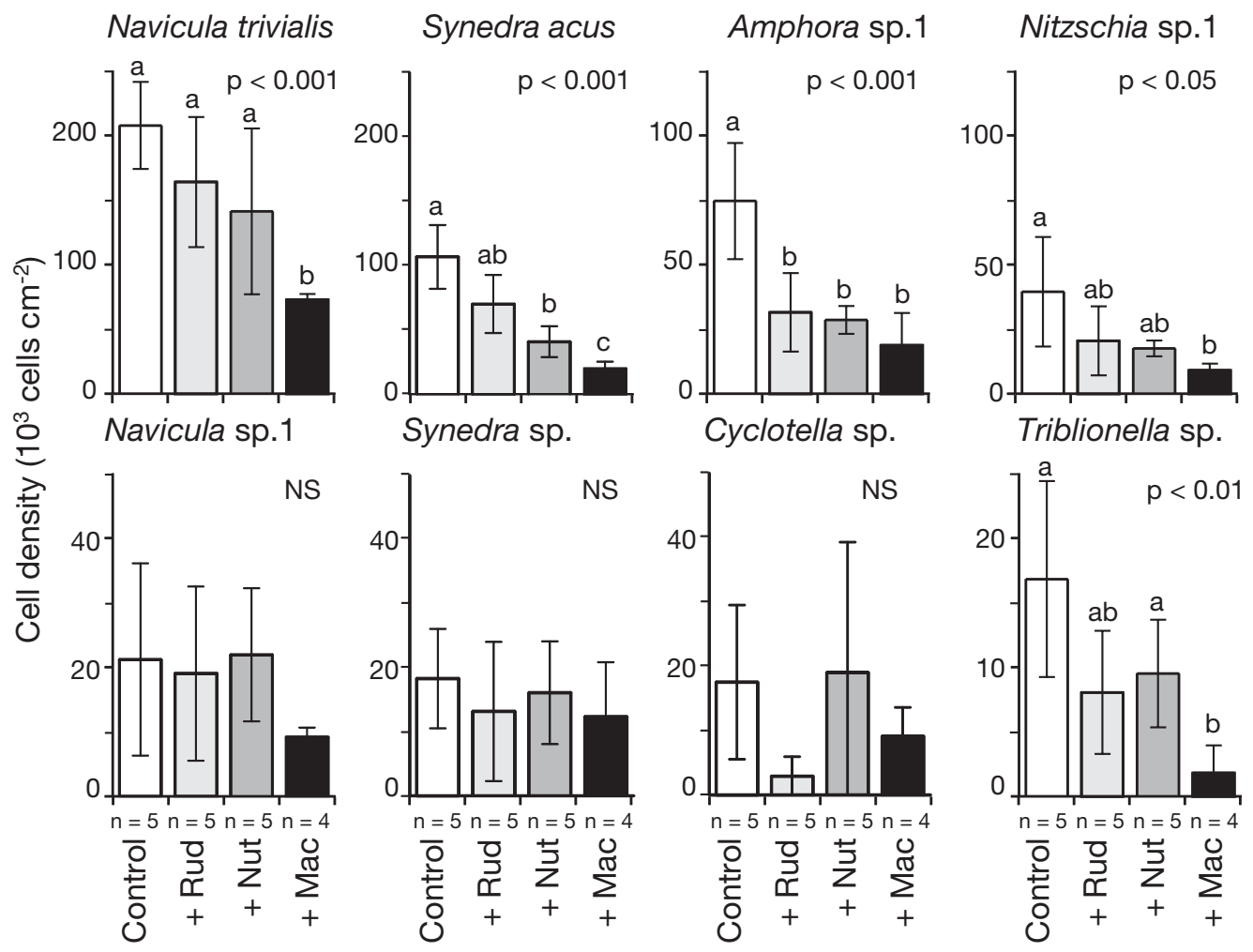

Type of treatment

Fig. 4. Densities $\left(10^{3}\right.$ cells $\left.\mathrm{cm}^{-2}\right)$ of the 8 dominant diatom species at the sediment surface. Bars represent mean $\pm 1 \mathrm{SD} ; \mathrm{p}$-values for 1-way ANOVA are shown; NS: not significant; different letters indicate significant differences between means (Bonferroni's multiple comparison, $\mathrm{p}<0.05$ ) 


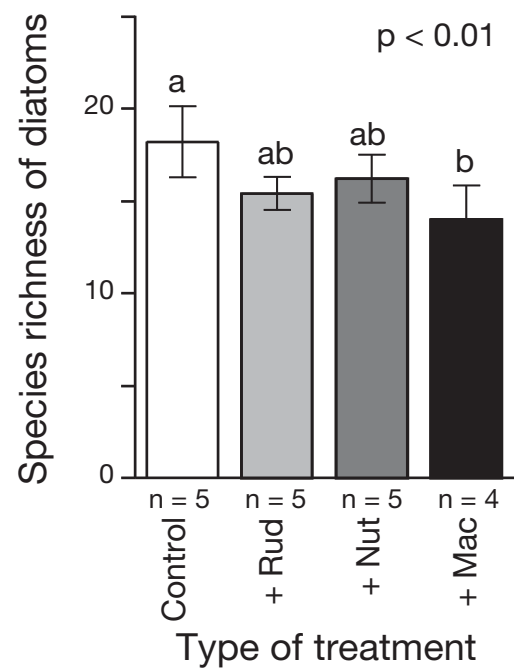

Fig. 5. Species richness of benthic diatoms at the sediment surface. Bars represent mean $\pm 1 \mathrm{SD}$; p-value for 1-way ANOVA is shown; different letters indicate significant differences between means (Bonferroni's multiple comparison, $\mathrm{p}<0.05$ )

values of SS, benthic diatoms, and enclosure sediment ranged from 7.3 to $9.1 \%$ (SS1, $9.1 \pm 1.2 \%$; $\mathrm{SS} 2,7.3 \pm$ $1.0 \%$; SS3, $8.3 \pm 0.9 \%$; and SS at Stn E, $7.4 \pm 4.3 \%$ o), 5.3 to $7.6 \%$ (BD1, $5.6 \pm 1.5 \%$; BD2, $7.6 \%$; and BD3, 5.3\%o), and 7.5 to $7.7 \%$ (control, $7.7 \pm 0.2 \%$; +Rud, $7.5 \pm 0.3 \%$; + Nut, $7.5 \pm 0.2 \%$; and + Mac, $7.6 \pm 0.2 \%$ ), respectively.

$\delta^{13} \mathrm{C}$ values of Ruditapes philippinarum significantly increased during the experiment (initial, $-20.5 \pm 0.1 \%$; final, $-18.9 \pm 0.3 \%$; $t$-test, $\mathrm{df}=4, t=-9.53, \mathrm{p}<0.001$ ), while those of Nuttallia olivacea and Macoma contabulata did not $(\mathrm{df}=4, t=-0.70$ and -0.07 , $\mathrm{p}>0.05$, respectively). A 2-source mixing model estimated that R. philippinarum gained more carbon from SS (61\%) in the natural habitat, while more from benthic diatoms $(62 \%)$ in the enclosures. In contrast, the deposit-feeding bivalves gained more carbon from benthic diatoms both at the natural habitats $(N$. olivacea, $69 \% ; M$. contabulata, $75 \%$ ) and in the enclosures ( $N$. olivacea, $73 \% ; M$. contabulata, $76 \%) . \delta^{15} \mathrm{~N}$ values of the bivalves also showed a tendency to shift (Fig. 7), but the changes were not significant ( $t$-test, $\mathrm{df}=4 ; R$. philippinarum, $t=-1.75 ; N$. olivacea, $t=-0.66$; and $M$. contabulata, $t=0.79$; $>0.05)$. The isotopic values of the bivalves seemed to approach the same point, approximately $-17.5 \%$ or for $\delta^{13} \mathrm{C}$ and $10 \%$ for $\delta^{15} \mathrm{~N}$.

Sediment $\delta^{13} \mathrm{C}$ values in the control $(-22.4 \pm 0.3 \%$, $+\operatorname{Rud}(-22.6 \pm 0.4 \%)$, and +Nut $(-22.4 \pm 0.3 \%$ ) enclosures had significantly increased from the initial value $(-23.7 \pm 0.3 \%)$ during the period ( $t$-test, $\mathrm{df}=6$; control, $t=6.61, \mathrm{p}<0.001 ;+$ Rud, $t=4.04, \mathrm{p}<0.01 ;+$ Nut,$t=$ $5.88, \mathrm{p}<0.01$ ), while not in the +Mac enclosures $(-23.7 \%$ o, df $=5, t=-0.04, p>0.05)$. The final sediment $\delta^{13} \mathrm{C}$ values differed significantly among the treat- (a) Absolute abundance

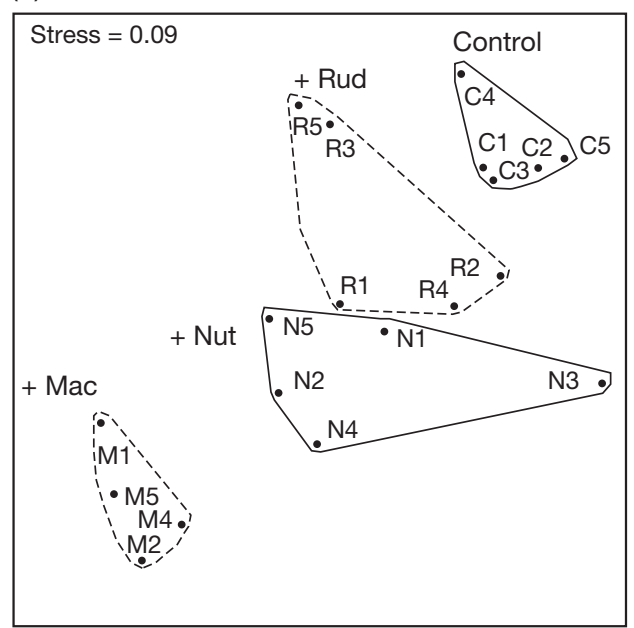

(b) Relative abundance

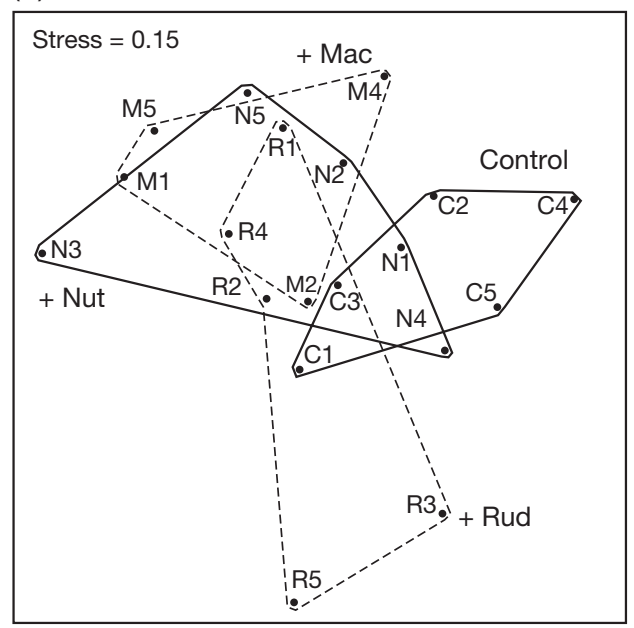

Fig. 6. MDS plots based on (a) the absolute abundances and (b) the relative abundances of benthic diatoms at the sediment surface in the enclosures. Inter-sample distance was measured using a Bray-Curtis coefficient

Table 5. A 1-way analysis of similarities (ANOSIM) showing significant differences in the benthic diatom communitystructure among the 4 treatments based on the Bray-Curtis similarity index, calculated from the absolute and relative abundances of benthic diatoms. The number of permutations was 999

\begin{tabular}{|c|c|c|c|c|}
\hline & \multicolumn{2}{|c|}{ Absolute abundance } & \multicolumn{2}{|c|}{ Relative abundance } \\
\hline & Global R & p-value & Global R & $\mathrm{p}$-value \\
\hline Treatments & 0.66 & $<0.001$ & 0.08 & $>0.05$ \\
\hline \multicolumn{5}{|c|}{ Pairwise comparison } \\
\hline Control, +Rud & 0.36 & $<0.05$ & & \\
\hline Control, +Nut & 0.76 & $<0.01$ & & \\
\hline Control, +Mac & 1.0 & $<0.01$ & & \\
\hline +Rud, +Nut & 0.02 & $>0.05$ & & \\
\hline +Rud, +Mac & 1.0 & $<0.01$ & & \\
\hline$+\mathrm{Nut}_{,}+\mathrm{Mac}$ & 0.71 & $<0.01$ & & \\
\hline
\end{tabular}




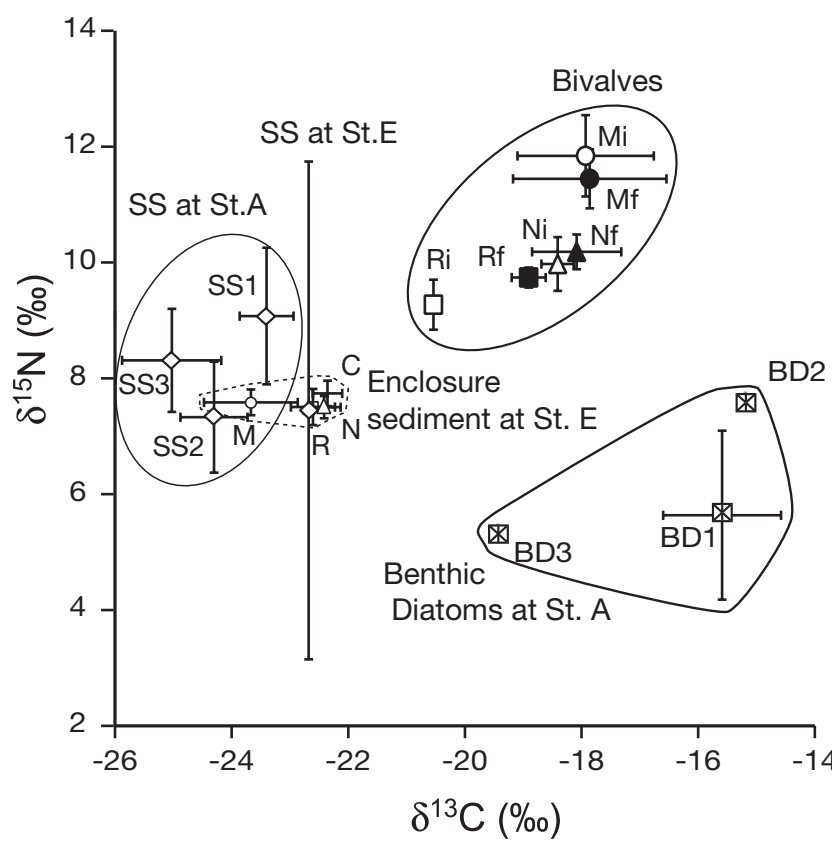

Fig. 7. Stable carbon and nitrogen isotope ratios (mean $\pm 1 \mathrm{SD})$. Ri \& Rf: initial and final values of Ruditapes philippinarum $(\mathrm{n}=3)$; Ni \& Nf: initial and final values of Nuttallia olivacea $(\mathrm{n}=3) ;$ Mi \& Mf: initial and final values of Macoma contabulata $(\mathrm{n}=3)$; BD1, BD2, \& BD3: benthic diatoms collected on 23 June $(\mathrm{n}=3)$, 20 July $(\mathrm{n}=1)$, and 25 August $2001(\mathrm{n}=1)$, respectively; SS1, SS2, and SS3: suspended solids with different sizes $(<25$, $25<75$, and $75<250 \mu \mathrm{m} ; \mathrm{n}=3$ ), respectively; $\mathrm{C}, \mathrm{R}, \mathrm{N}$, and $\mathrm{M}$ : surface sediment of the control $(\mathrm{n}=5),+$ Rud $(\mathrm{n}=5),+$ Nut $(\mathrm{n}=5)$, and +Mac $(\mathrm{n}=4)$ enclosures. BD4 $\left(\delta^{13} \mathrm{C}=-18.4 \%\right)$ was not plotted because of missing $\delta^{15} \mathrm{~N}$ value

ments, while $\delta^{15} \mathrm{~N}$ values did not (Table 2). The value in the +Mac treatment was 1.1 to $1.4 \%$ lower than those in the other treatment (Bonferroni's multiple comparison, $\mathrm{p}<0.05$, Fig. 7), while there were no significances among the control, +Rud, and +Nut treatments $(\mathrm{p}>0.05)$.

\section{DISCUSSION}

\section{Sediment modification}

Our data showed that sediment modifications by bivalves clearly differed among the 3 studied species. Only Macoma contabulata sharply reduced silt-clay, TN, and TOC contents (Fig. 2), suggesting that it depends more on surface-deposit feeding than Nuttallia olivacea. The lowest diatom density (Fig. 3b) also indicated that $M$. contabulata imposed the highest feeding pressure on the sediment. $N$. olivacea did not change the silt-clay, TN, and TOC contents, although the benthic diatom densities were significantly re- duced. $N$. olivacea conducts deposit feeding, as well as $M$. contabulata; however, $N$. olivacea might be more selective about food during ingestion and/or digestion and, as a result, bioturbate the sediment differently.

Ruditapes philippinarum was expected to cause biodeposition; however, it did not increase the organic content, but reduced the diatom density like the deposit feeder Nuttallia olivacea (Figs. 2 \& 3). These figures indicate that this species could ingest a certain amount of the benthic diatoms, although it apparently does not directly siphon them. It has been reported that resuspension of the sediment provides benthic diatoms to benthic suspension feeders (Plante-Cuny \& Plante 1986, Miller et al. 1996). In our experiment, wind waves may have disturbed the raised enclosure sediment, and the siphon currents of $R$. philippinarum could also have resuspended the sediment near the burrow. Ingestion of the resuspended particles by $R$. philippinarum would make the biodepositional effects inconspicuous. Considering the smaller shell size (i.e. lower biomass, Table 1), R. philippinarum possibly has a much higher feeding pressure on benthic diatoms than does $N$. olivacea.

Chl a content was significantly higher in +Rud although the benthic diatom decreased (Fig. 3). It implies that microalgae other than diatoms increased at the sediment surface. During laboratory observations, we sometimes found filamentous macroalgae (remaining on a $0.25 \mathrm{~mm}$ mesh, unidentified, $<1 \mathrm{~cm}$ long) in the control and +Rud sediment (not quantitative data). The algal mats possibly contributed to the high chl a content. It has been reported that some suspension-feeding bivalves promote nutrient release from the sediment and increase the microalgal biomass (Swanberg 1991). Thus, Ruditapes philippinarum might promote the growth of phytobenthos at the sediment surface.

The $\delta^{13} \mathrm{C}$ value and $\mathrm{C} / \mathrm{N}$ ratio are widely used as source indicators of organic matter in aquatic ecosystems (e.g. Fry \& Sherr 1984, Meyers 1994, Thornton \& McManus 1994). Sediment $\delta^{13} \mathrm{C}$ value in the control $(-22.4 \%)$, +Rud (-22.6\%o), and +Nut (-22.4\%o) enclosures increased significantly from the initial value $(-23.7 \%)$, but not in the +Mac treatment $(-23.7 \%)$. The carbon stable isotopic enrichments would be due to the increase in benthic diatoms with high $\delta^{13} \mathrm{C}$ values $(-19.4$ to $-15.2 \%)$ during the period. It seemed that the lower final sediment $\delta^{13} \mathrm{C}$ values in the +Mac treatment reflect the decrease of benthic diatoms under high feeding pressure. $\mathrm{C} / \mathrm{N}$ ratios were also higher in the + Nut and +Mac treatments (9.4 and 9.2) than in the control (8.3, Fig. 3c). It has been reported that the C/N ratio of microalgae ranges from 3 to 8 in general (Meyers 1994), while those of deposited SS were 9 to 10 in the Gamo lagoon (Toya 1997, Kurata et al. 2001). 
Therefore, the high $\mathrm{C} / \mathrm{N}$ ratios should also be due to the removal of benthic diatoms with low $\mathrm{C} / \mathrm{N}$ ratios. In the +Rud enclosures, increasing phytobenthic biomass (chl a) would offset the decrease of benthic diatoms.

In conclusion, our data revealed the importance of infaunal bivalves as consumers of benthic diatoms and the strong connection between the bivalve species identity and benthic diatoms, regardless of their feeding mode. Our data also showed that suspensionfeeding bivalves are potentially strong reducers of benthic diatoms, as well as surface-deposit feeders. In this study, the inter- or intra-species interactions among bivalves were not considered. Therefore, the combined effects of bivalves must be known, in order to understand their role as bioturbators in natural environments.

\section{Benthic diatoms}

Our data showed that the total densities of benthic diatoms were reduced differently by the 3 bivalve species (Fig. 3b). All the bivalve species significantly reduced the densities of Synedra acus and Amphora sp. 1, while Macoma contabulata specifically reduced the densities of Navicula trivialis, Nitzschia sp. 1, and Triblionella sp. (Fig. 4). Furthermore, the high feeding pressure of $M$. contabulata on the sediment surface reduced the species richness of the benthic diatom assemblage, while the deposit-feeder, Nuttallia olivacea, and the suspension-feeder, Ruditapes philippinarum, did not (control, 18.2; +Rud, 15.4; +Nut, 16.0; +Mac, 14.4; Fig. 5). These results imply a specific modification of the benthic community structure by the bivalve species in relation to their feeding ecology.

MDS and 1-way ANOSIM (Fig. 6, Table 5) showed that the bivalve species modified diatom community structures in different ways by changing the abundances and composition, whereas they hardly changed the relative abundances. Microphytobenthos are known to have various cell sizes ( $>100$ to $3 \mu \mathrm{m}$ ) and various life forms, e.g. attached to sand grains versus mobile (Reise 1992); however, these results imply that the feeding activities of bivalves, such as particle collection, filtration, and rejection, occur with low or no selectivity toward the diatom species. Our results were similar to a previous study using a deposit-feeding bivalve (Macoma nasuta). Page et al. (1992) reported that $M$. nasuta did not clearly change the relative abundance of benthic diatom species, although it sharply reduced the total diatom density.

In conclusion, infaunal bivalves, especially for surface-deposit feeders, would play an important role in structuring the benthic diatom community in shallow, soft-bottom environments. However, the feeding be- haviors of deposit- and suspension-feeding bivalves seem to exhibit little to no selectivity towards benthic diatoms compared to other benthic consumers, such as amphipods, polychaetes, and gastropods (Connor \& Edgar 1982, Smith et al. 1996, Hillebrand et al. 2000, Hagerthey et al. 2002).

\section{Food sources of bivalves}

Values of $\delta^{13} \mathrm{C}$ generally remain nearly constant throughout the food chain, or there is a $\sim 1 \%$ onrichment with each trophic step (Fry \& Sherr 1984), whereas $\delta^{15} \mathrm{~N}$ values increase about 3 to $4 \%$ with each trophic transfer (Minagawa \& Wada 1984). Thus, the $\delta^{13} \mathrm{C}$ value of a consumer is expected to be close to that of its assimilated diet.

Final $\delta^{13} \mathrm{C}$ values of Nuttallia olivacea $(-18.1 \%$ ) and Macoma contabulata $(-17.9 \%$ ) were much closer to those of benthic diatoms $(-19.4$ to $-15.2 \%)$ than to that of SS $(-25.0$ to $-22.7 \%$ ) or the enclosure sediment (Fig. 7). Final $\delta^{15} \mathrm{~N}$ values of $N$. olivacea (10.2\%) and M. contabulata $(11.4 \%$ ) were 3 to $6 \%$ higher than those of benthic diatoms (5.3 to $7.6 \%$ ), probably reflecting trophic enrichment. A 2-source mixing model confirmed that $N$. olivacea and $M$. contabulata gained $>69 \%$ of the carbon from benthic diatoms $(<31 \%$ from SS), both in natural habitats and in the enclosures. Therefore, benthic diatoms should be the more important food source for the deposit-feeding bivalves in the lagoon.

Both Ruditapes philippinarum and Nuttalia olivacea reduced diatom density (Fig. 2) and had similar final $\delta^{13} \mathrm{C}$ values ( $-18.9 \%$ and $-18.1 \%$, respectively), which were much closer to those of benthic diatoms $(-19.4$ to $-15.2 \%$ ) than to that of the SS $(-25.0$ to $-22.7 \%$ o) (Fig. 7). Judging from the isotopic value shifts during the period, which approached a common value (Fig. 7 ), the 3 bivalve species appeared to assimilate the same diet in the enclosures. A 2-source mixing model also estimated that $61 \%$ of the carbon of $R$. philippinarum (final) was derived from benthic diatoms. However, we should be careful about surmising food sources, since suspension feeders sometimes have $\delta^{13} \mathrm{C}$ values 3 to $5 \%$ higher than those of SS (Fry \& Sherr 1984). In our study, the finer fraction of SS (SS1) seemed to be more important to the diet, since $R$. philippinarum selectively rejects larger particles $(>7.5$ to $>22.5 \mu \mathrm{m}$ ) as pseudofeces (Defossez \& Hawkins 1997). Considering the $\delta^{15} \mathrm{~N}$ values, those of $R$. philippinarum (final; $9.7 \pm 0.2 \%$ ) did not agree with the expected value when it primarily assimilated the SS1 fraction $(9.1 \pm 1.2 \%$ o). Therefore, $R$. philippinarum appears to predominantly assimilate benthic diatoms in the enclosures. 
It was also remarkable that the $\delta^{13} \mathrm{C}$ value of $\mathrm{Rudi}$ tapes philippinarum significantly increased $(1.6 \%)$ during the period. A 2-source mixing model estimated that contribution of SS-derived carbon to $R$. philippinarum decreased from $61 \%$ (initial) to $39 \%$ (final). The dietary change may partially be caused by the stimulated resuspension of the benthic diatoms being due to the raised enclosure sediment. Another possible factor is the lower tidal currents at Stn E $\left(<2 \mathrm{~cm} \mathrm{~s}^{-1}\right)$ compared to those at the natural habitat (Stn R, 15 to $25 \mathrm{~cm} \mathrm{~s}^{-1}$, Aikins \& Kikuchi 2001). Sobral \& Widdows (2000) reported that a suspension-feeding bivalve often causes a small-scale depletion of suspended algal cells under a low current velocity $\left(<8 \mathrm{~cm} \mathrm{~s}^{-1}\right)$. Therefore, SS in the water column may be easily used up at Stn E, and, in this case, benthic diatoms would become a more important diet. Although the mechanisms are still unknown, the relative dietary importance of SS and benthic diatoms for suspension feeders could be changed in relation to the supply of SS and resuspended sediment.

Acknowledgements. We would like to thank Dr. K. Ito for allowing us to use the elemental analyzer and the mass spectrometer at the Department of Agriculture, Tohoku University. Special thanks to K. Sato for his assistance in experimental planning, to K. Kanou for his assistance in field work, to Dr. K. Fujiwara and M. Fujikawa for their help in stable isotope analyses, and to Dr. H. Doi for his valuable suggestions. We are also grateful to Dr. L. A. Levin and 3 anonymous referees for their reviewing, advising, and critical comments on the manuscript. This study was partly supported by Grant-in-Aid for Scientific Research (C) from Japan Society for the Promotion of Science (No. 17570012).

\section{LITERATURE CITED}

Aikins S, Kikuchi E (2001) Water current velocity as an environmental factor regulating the distribution of amphipod species in Gamo lagoon, Japan. Limnology 2:185-191

Akiyama A (1988) Benthic animals in an intertidal flat. In: Kurihara Y (ed) Ecology and ecotechnology in estuarinecoastal area. Tokai University Press, Tokyo, p 85-98 (in Japanese)

Bartoli M, Nizzoli D, Viaroli P, Turolla E (2001) Impact of Tapes philippinarum farming on nutrient dynamics and benthic respiration in the Sacca di Goro. Hydrobiologia 455:203-212

Cahoon LB (1999) The role of benthic microalgae in neritic ecosystems. Oceanogr Mar Biol Annu Rev 37:47-86

Chihara M, Murano M (1997) An illustrated guide to marine plankton in Japan. Tokai University Press, Tokyo (in Japanese)

Clarke KR, Gorley RN (2001) PRIMER v5: user manual/ tutorial. PRIMER-E, Plymouth Press, Plymouth

Connor MS, Edgar RK (1982) Selective grazing by the mud snail Ilyanassa obsolete. Oecologia 53:271-275

Couch CA (1989) Carbon and nitrogen stable isotopes of meiobenthos and their food resources. Estuar Coast Shelf Sci 28:433-441

Defossez JM, Hawkins AJS (1997) Selective feeding in shellfish: size-dependent rejection of large particles within pseudofaeces from Mytilus edulis, Ruditapes philippinarum and Tapes decussatus. Mar Biol 129:139-147

France RL, Peters RH (1997) Ecosystem differences in the trophic enrichment of $\delta^{13} \mathrm{C}$ in aquatic food webs. Can J Fish Aquat Sci 54:1255-1258

Fry B, Sherr EB (1984) $\delta^{13} \mathrm{C}$ measurements as indicators of carbon flow in marine and freshwater ecosystems. Contrib Mar Sci 27:13-47

Graf G, Rosenberg R (1997) Bioresuspension and biodeposition: a review. J Mar Syst 11:269-278

Hagerthey SE, Defew EC, Paterson DM (2002) Influence of Corophium volutator and Hydrobia ulvae on intertidal benthic diatom assemblages under different nutrient and temperature regimes. Mar Ecol Prog Ser 245:47-59

Heip CHR, Goosen NK, Herman PMJ, Kromkamp J, Middleburg JJ, Soetaert K (1995) Production and consumption of biological particles in temperate tidal estuaries. Oceanogr Mar Biol Annu Rev 33:1-149

Hillebrand H, Worm B, Lotze HK (2000) Marine microbenthic community structure regulated by nitrogen loading and grazing pressure. Mar Ecol Prog Ser 204:27-38

Kojima S, Sudo R, Chihara M (1995) An illustrated book of environmental microorganisms. Kodan-sya, Tokyo (in Japanese)

Kurata K, Minami H, Kikuchi E (2001) Stable isotope analysis of food sources for salt marsh snails. Mar Ecol Prog Ser 223:167-177

Kurihara Y, Kikuchi E, Uehara T, Suzuki T (2000) Report of fundamental investigation of environmental conservation measure for Gamo tidal flat in 1999. Miyagi Prefecture, Sendai (in Japanese)

Lopez GR, Levinton JS (1987) Ecology of deposit-feeding animals in marine sediments. Q Rev Biol 62:235-260

MacIntyre HL, Geider RJ, Miller DC (1996) Microphytobenthos: the ecological role of the 'secret garden' of unvegetated, shallow-water marine habitats. I. Distribution, abundance and primary production. Estuaries 19:186-201

McCune B, Mefford MJ (1999) PC-ORD: multivariate analysis of ecological data, version 4. MjM Software Design, Gleneden Beach, OR

Meyers PA (1994) Preservation of elemental and isotopic source identification of sedimentary organic matter. Chem Geol 114:289-302

Miller DC, MacIntyre HL, Geider RJ (1996) Microphytobenthos: the ecological role of the 'secret garden' of unvegetated, shallow-water marine habitats. II. Role in sediment stability and shallow-water food webs. Estuaries 19: 202-212

Minagawa M, Wada E (1984) Stepwise enrichment of ${ }^{15} \mathrm{~N}$ along food chains: further evidence and the relation between $\delta^{15} \mathrm{~N}$ and animal age. Geochim Cosmochim Acta 48:1135-1140

Mizuno T (1964) Illustrations of the freshwater plankton of Japan. Hoiku-sha, Osaka (in Japanese)

Navarro JM, Thompson RJ (1997) Biodeposition by the horse mussel Modiolus modiolus (Dillwyn) during the spring diatom bloom. J Exp Mar Biol Ecol 209:1-13

Page HM (1997) Importance of vascular plant and algal production to macro-invertebrate consumers in a southern California salt marsh. Estuar Coast Shelf Sci 45:823-834

Page HM, Dugan JE, Hubbard DM (1992) Comparative effects of infaunal bivalves on an epibenthic microalgal community. J Exp Mar Biol Ecol 157:247-262

Phillips DL, Koch PL (2002) Incorporating concentration dependence in stable isotope mixing models. Oecologia 130:114-125 
Plante-Cuny MR, Plante R (1986) Benthic marine diatoms as food for benthic marine animals. In: Richard M (ed) Proceedings of the 8th international diatom symposium. Koeltz Scientific Books, Königstein, p 525-537

Reise K (1992) Grazing on sediment shores. In: John DM, Hawkins SJ, Price JH (eds) Plant-animal interactions in the marine benthos. Systematics Association Spec Vol 46, Clarendon Press, Oxford, p 133-145

Rhoads DC (1974) Organism-sediment relations on the muddy sea floor. Oceanogr Mar Biol Annu Rev 12 263-300

Self RFL, Jumars PA (1988) Cross-phyletic patterns of particle selection by deposit feeders. J Mar Res 46: 119-143

Smith D, Hughes RG, Cox EJ (1996) Predation of epipelic diatoms by the amphipod Corophium volutator and the polychaete Nereis diversicolor. Mar Ecol Prog Ser 145: 53-61

Sobral P, Widdows J (2000) Effects of increasing current velocity, turbidity and particle size selection on the feeding activity and scope for growth of Ruditapes decussatus from Ria Formosa, southern Portugal. J Exp Mar Biol Ecol 245:111-125

Swanberg IL (1991) The influence of the filter-feeding bivalve

Editorial responsibility: Lisa Levin (Contributing Editor), La Jolla, California, USA
Cerastoderma edule L. on microphytobenthos: a laboratory study. J Exp Mar Biol Ecol 151:93-111

Takano H (1990) Bacillariophyceae. In: Fukuyo Y, Takano H, Chihara M, Matsuoka K (eds) Red tide organisms in Japan - an illustrated taxonomic guide. Uchida Rokakuho, Tokyo, p 162-330 (in Japanese)

Thornton SF, McManus J (1994) Application of organic carbon and nitrogen stable isotope and $\mathrm{C} / \mathrm{N}$ ratios as source indicators of organic matter provenance in estuarine systems: evidence from the Tay Estuary, Scotland. Estuar Coast Shelf Sci 38:219-233

Toya T (1997) The relationships between macrobenthos, bottom characteristics and sinking material in estuarine tidal flat. MSc thesis, Graduate School of Science, Tohoku University (in Japanese)

Tsuchiya M, Kurihara Y (1980) Effect of the feeding behavior of macrobenthos on changes in environmental conditions of intertidal flats. J Exp Mar Biol Ecol 44:85-94

Whitney DE, Darley WM (1979) A method for determination of chlorophyll $a$ in samples containing degradation products. Limnol Oceanogr 24:183-186

Yamaji I (1966) Illustrations of the marine plankton of Japan. Hoiku-sya, Osaka (in Japanese)

Submitted: April 27, 2004; Accepted: March 17, 2005

Proofs received from author(s): August 8, 2005 